\title{
WATER DEFICIT AS A SECURITY THREAT
}

The Earth is known as the Blue Planet, for 75 per cent of its surface is covered by water. Importantly only 2.5 per cent of the Earth's waters are fresh, which are essential for the life of man and other living organisms. Among all the resources of drinking water, as much as 68.9 per cent is in the form of glacial ice, which is not readily available to man. Those resources serving the needs of fresh water originate foremost from subterranean reservoirs - approximately 30.8 per cent of drinking water and from rivers and lakes - amounting to about 0.3 per cent (Blanchon, 2013: 10).

Water is used across the globe as much as 70 per cent in agriculture, 20 per cent in industry (including the production of energy), 10 per cent for the purposes of home use (The World Bank, 2010: 172). The use of water itself differs greatly in particular regions. Agriculture consumes the most, respectively about 82 per cent and 81 per cent in Africa and Asia, and the least in Europe, some 22 per cent. In turn on the European continent the greatest exploitation of water is recorded in industry, some 57 per cent (UNESCO, 2015: 41).

The amount of fresh water on Earth is relatively constant and amounts to approximately 1,400 millions cubic kilometres, and the Earth's population according to the most likely United Nations prediction ${ }^{1}$ will increase to over 8.5 billion in 2030 and about 9.7 in 2050 . As a consequence, interested parties shall have to increasingly often analyse the very purpose of these invaluable resources and at the same time, competition over water between rural and urbanised areas shall intensify (Water for Life, 2015: 1). The situation is worsened by the fact that the predicted demographic growth in this respect is concentrated in regions such as Asia and Africa where at present there occur crises related to the availability of water. The predicted increase in population up to 2100 , divided into geographic regions is presented by Table 1 .

This article therefore aims to present concepts related to water security, also known as hydrological security, as well as to indicate the nature of respective threats caused by crises related to the need for exploitation of water as a fundamental resource for the functioning of mankind.

1 Among the five projections of population growth prepared by the United Nations, by the end of the $21^{\text {st }}$ century the medium variant is seen as the most likely. That variant "assumes a decline of fertility for countries where large families are still prevalent, as well as a slight increase of fertility in several countries with fewer than two children per woman on average. [...] one can say with a 95 per cent degree of confidence that global population will be between 8.4 and 8.6 billion in 2030 and between 9.5 and 13.3 billion in 2100" (United Nations Department of Economic and Social Affairs, Population Division, 2015: 3). 
Population of the world and major areas for 2015, 2030, 2050 and 2100 , according to the medium-variant projection of the UN

\begin{tabular}{|l|r|r|r|r||}
\hline \multirow{2}{*}{\multicolumn{2}{c|}{ Major area }} & \multicolumn{3}{c|}{ Population (millions } \\
\cline { 2 - 5 } & $\mathbf{2 0 1 5}$ & $\mathbf{2 0 3 0}$ & $\mathbf{2 0 5 0}$ & $\mathbf{2 1 0 0}$ \\
\hline World & 7,349 & 8,501 & 9,725 & 11,213 \\
\hline Africa & 1,186 & 1,679 & 2,478 & 4,387 \\
\hline Asia & 4,393 & 4,923 & 5,267 & 4,889 \\
\hline Europe & 738 & 734 & 707 & 646 \\
\hline Latin America and the Caribbean & 634 & 721 & 784 & 721 \\
\hline Northern America & 358 & 396 & 433 & 500 \\
\hline Oceania & 39 & 47 & 57 & 71 \\
\hline \hline
\end{tabular}

Source: United Nations Department of Economic and Social Affairs/Population Division (2015), World Population Prospects: The 2015 Revision, Key Findings and Advance Tables, New York, p. 1.

\section{DEFINING WATER SECURITY, WATER SCARCITY AND WATER STRESS}

Water security is a concept advanced by the United Nations Development Programme (UNDP) as part of its human-security agenda: "Water security is about ensuring that every person has reliable access to enough safe water at an affordable price to lead a healthy, dignified, and productive life, while maintaining ecological systems that provide water and also depend on water" (Magsig, 2015: 30). That explanation brings four dimensions of water security:

1) physical water availability,

2) economical water access,

3) access to clean, safe drinking water,

4) sustainable water resources management.

In 2013 experts of the UN Water, an inter-agency coordination mechanism for all freshwater-related issues, proposed a definition of water security as: "the capacity of a population to safeguard sustainable access to adequate quantities of acceptable quality water for sustaining livelihoods, human well-being, and socio-economic development, for ensuring protection against water-borne pollution and water-related disasters, and for preserving ecosystems in a climate of peace and political stability" (Water Security, 2013: 1).

That interpretation of water security enlarges the concept by referring to the ability to prevent or minimize the consequences of disaster such as floods or droughts. The authors of the above definition have decided to underline that all elements of water security should be achieved by local or regional communities and by states or between them, without using force. That aspect shows a concern about the influence of water-related issues on internal and international relations.

Lack of water security is described by the term "water scarcity", which means "the point at which the aggregate impact of all users impinges on the supply or quality of water under prevailing institutional arrangements to the extent that the demand by all sec- 
tors, including the environment, cannot be satisfied fully" (Water stress versus, 2014). More than a billion people live in regions of physical water scarcity, while another 1.6 billion struggle with economic water shortage (Kumar, 2013: 96). According to the World Resources Institute's estimates 3.5 billion people could experience water scarcity by 2025 (Water. Mapping, measuring, 2015).

Hydrologists assess scarcity by analysing the population-water equation. Water stress occurs when annual water supplies in the country (or other defined territory) drop below 1,667 cubic meters per capita. Annual water supplies lower than 1,000 cubic meters per person means that the population faces water scarcity, and lower than 500 cubic meters "absolute scarcity". This scale was developed by Swedish hydrologist Professor Malin Falkenmark, who believes that nations suffering absolute water scarcity face a "water barrier", meaning they face serious difficulties in development (Chalecki, 2013: 28). According to the World Bank by 2025, about 1.8 billion people will be living in regions or countries with absolute water scarcity (Water Overview, 2015).

Further, water is not distributed equally around the world. The long-term annual average of renewable freshwater resources per person, measured over at least 20 years, is recorded on a very high level for example in Congo, Canada or Brazil, where the indicator is respectively $230,142,83,931$ and 43,891 cubic meters. Among countries with a radically different water exploitation context is respectively Israel -237 , Jordan - 143, Libya - 95, UAE - 33 and Kuwait - 7 cubic meters per capita during the year (Environmental Indicators, Inland Water Resources, 2011).

\section{Map 1. Total renewable water resources per inhabitant $\left(\mathrm{m}^{3} /\right.$ year $)$}

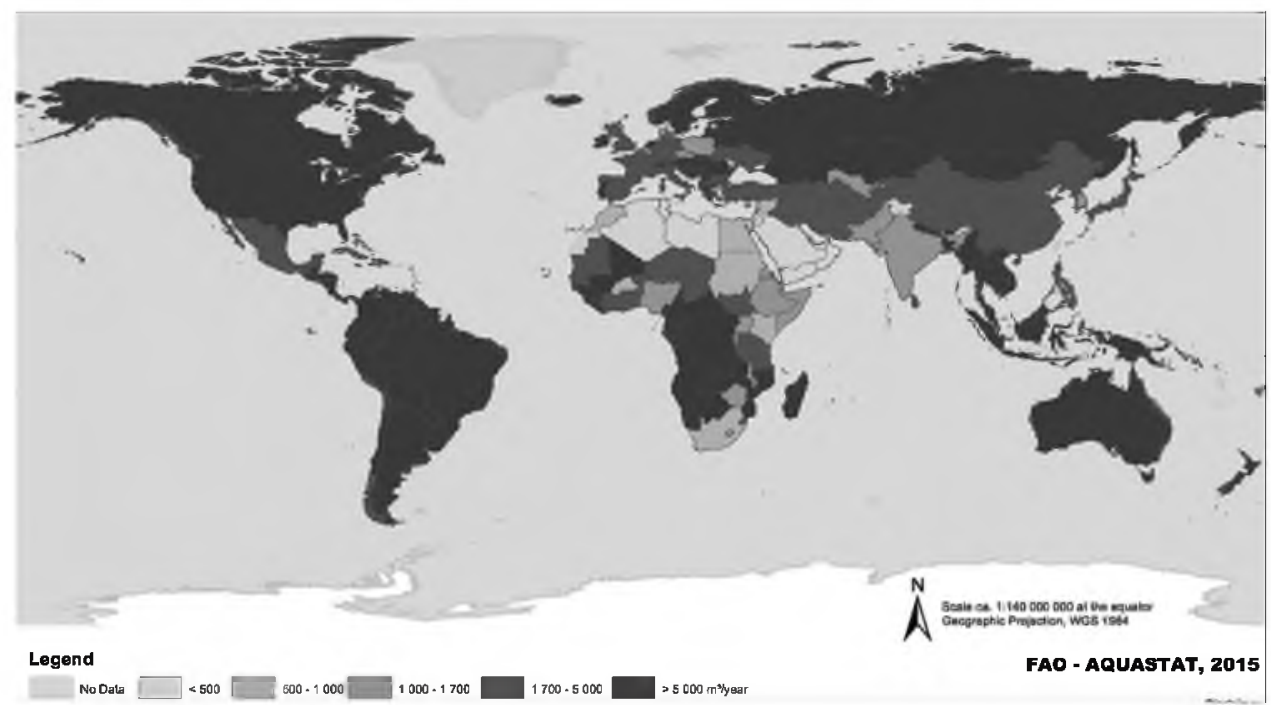

Source: Food and Agriculture Organization of the United Nations global water information system AQUASTAT, http:/www.fao.org/nr/water/aquastat/maps/index.stm (8.01.2016).

The impacts of water scarcity are felt most acutely in the arid regions of the world but factors like climate change and rapid urbanization have increased water stress for 
other regions and consequently competition for water between urban and rural areas will grow. By 2030 , food demand is expected to increase by 50 per cent ( 70 per cent by 2050), while energy demand from hydropower and other renewable energy resources will rise by 60 per cent (UN Water, 2012: 46). All forms of energy need water at some stage of their life cycle, which will be needed for the purposes of production, conversion, distribution or use. Moreover, especially in Africa, domestic competition for water and land is taking place between farmers/herders from different tribes such as the Dinka and the Nuer in South Sudan. Conflicts between farmers and herders are also common as for example in Sudanese Darfur (Sakson, 2013).

\section{WATER CONFLICTS OR WATER COOPERATION}

In this context conflicts between nations over water resources may be seen as highly probable on account of the large number of countries sharing the tributary, as presented by Table 2 .

\section{Number of states sharing a basin}

\begin{tabular}{|c|c|}
\hline $\begin{array}{l}\text { Number } \\
\text { of states }\end{array}$ & International Basins \\
\hline 3 & $\begin{array}{l}\text { Asi (Orontes), Awash, Cavally, Cestos, Chiloango, Dnieper, Dniester, Ebro, Essequibo, Gambia, } \\
\text { Garonne, Gash, Geba, Har Us Nur, Hari (Harirud), Helmand, Hondo, Ili, Icomati, Irrawadd,, } \\
\text { Juba-Shibeli, Kemi, Lake Prespa, Lake Titicaca-Poopo System, Lempa, Maputo, Maritsa, Maroni, } \\
\text { Moa, Neretva, Ntem, Ob, Oueme, Pasvik, Red, Rhone, Ruvuma, Salween, Sanaga, Schelde, Seine, } \\
\text { St. John, Sulak, Talas, Torne, Tumen, Umbeluzi, Volga and Zapaleri }\end{array}$ \\
\hline 4 & $\begin{array}{l}\text { Amur, Daugava, Drin, Elbe, Indus, Komoe, Lake Turkana, Limpopo, Lotagipi, Swamp, Narva, } \\
\text { Oder, Ogooue, Okavango, Orange, Po, Pu-Lun-T'o, Senegal, Struma, and Vardar }\end{array}$ \\
\hline 5 & La Plata, Neman, and Vistula \\
\hline 6 & $\begin{array}{l}\text { Aral Sea, Ganges-Brahmaputra-Meghna, Jordan, Kura-Araks, Mekong, Tarim, Tigris-Euphrates, } \\
\text { and Volta }\end{array}$ \\
\hline 8 & Amazon and Lake Chad \\
\hline 9 & Rhine and Zambezi \\
\hline 11 & Congo, Niger, and Nile \\
\hline 18 & Danube \\
\hline
\end{tabular}

Source: P. MacQuarrie, A. T. Wolf (2013), Understanding Water Security, in: Environmental Security, (eds.) R. Floyd, R. A. Matthew, Abington-New York, p. 171.

According to UN Water, there are 276 trans-boundary river basins worldwide, of which: 68 are in Europe, 64 in Africa, 60 in Asia, 46 in North America and 38 in South America. A total of 148 countries include territory within one or more international river basin (There are 276 transboundary, 2014). The trans-boundary Waters Assessment Programme held under United Nations Environment Programme (UNEP) describes an additional 10 trans-boundary river basins, which means 286 in total (The Global Transboundary, 2015). As indicated in Table 2, the maximum is 18 countries 
sharing a basin (Danube River). Moreover around 200 trans-boundary aquifers have been identified - most of them are in South East Europe and Africa, respectively 65 and 40 (Atlas, 2009: 61).

The issue of water resources and their impact on relations between nations is influenced by how much a country depends on other countries for its total water resources. In the case of Bangladesh, Botswana, Bulgaria, Egypt, Hungary, Mauretania, Moldova, Niger, Namibia, Rumania, Sudan, Turkmenistan, Pakistan, Uzbekistan and The Netherlands, trans-boundary water contributes between 75 per cent and 100 per cent to the total renewable water resources, while for Argentina, Benin, Cambodia, Chad, Eritrea, Iraq, Israel, Latvia, Mozambique, Paraguay, Portugal, Republic of the Congo, Slovakia, Somalia, Syria, Ukraine, Vietnam, some 50-75 per cent (Contribution of, 2015).

In 1995, during an interview for "The New York Times", Ismail Serageldin - the World Bank's vice president for Environmentally Sustainable Development, has said: "Many of the wars in this century were about oil, but wars of the next century will be over water" (Crossette, 1995). As questions about water management and international conflict appeared, researchers at Oregon State University analysed conflict and cooperation between states over international water resources that had occurred over 60 years (1948-2008). The International Water Event Database had been created where incidents were categorized in the following sections: infrastructure, water quantity, joint management, water quality, hydropower, flood control, technical cooperation, and "others" are classified by intensity: ranging from -7 (the most conflictive event, formal declaration of war over water) to +7 (the most cooperative event, voluntary unification into one nation over water). A zero value represents neutral or non-significant acts (BAR Scale, 2011).

The study documents a total of 2,586 water-related states interactions among which:

- 21 were connected with extensive war acts causing deaths, dislocation or high strategic costs. For example between 1969 and 1970 Israel attacks the Jordan East Ghor Canal (including bombings) eight times. Jordan had planned to extend the Canal by 8 kilometers to develop the agricultural sector but failed as Israel chooses to force the Jordanian government to stop the Palestinian fighters (fedayeen) by destroying hydro-technical construction. As a result thousands Jordanians flee the area (Sosland, 2007: 97-98);

- 17 brought small-scale military acts, as on January 1989 when clashes over irrigation facilities between Kyrgyzstan \& Tajikistan residents broke out in the Fergana valley, which is a part of the Aral Sea basin. After the collapse of the Soviet Union, Kyrgyz-Tajik relations in the region stay tense and Kyrgyz accuse Tajiks of stealing from limited water supplies, which led to ethnic violence in southern Kyrgyzstan (Vela, 2011);

- 6 resulted in political-military hostile actions such as for example, the Croatian War of Independence. After blowing up a part of the water supply pipeline on 3 June 1994 in the village of Kakma, the Croatian Chamber of Deputies adopted a Resolution on condemnation of the genocide in the form of mass terrorism and violence perpetrated by occupying Serbian authorities by disabling water supply of Biograd and Zadar with the surroundings. The resolution was sent to European 
countries, the United Nations, and International War Crimes Tribunal to inform of the water situation in Biograd, which for 3 years had been suffering a shortage of water (Roller, 1994);

- 68 lead to diplomatic-economic hostile actions. Examples are Bengali-Indian relations over the Ganges-Brahmaputra-Megha basin. In 2006 Bangladesh protests to India about falling water levels in the Ganges river, in violation of the 1996 bilateral Treaty on Sharing of the Ganga that regulate the downstream flow into Bangladesh for the duration of 30 years (International Water Events, 2011);

- 227 brought strong verbal expressions displaying hostility in interactions such as in 2006 when India launched an official protest to Pakistan over the proposed construction of the Bhasha damn over a section of the River Indus that flowed through Kashmir territory, which was in dispute. According to the foreign minister's statement "the project would result in the flooding of large parts of land India considers to be its territory" (India protest, 2006). Pakistan, who does not accept India's sovereignty over Kashmir, rejected the protest, claiming all decisions concerning riparian and infrastructural facilities are to be decided according to UN resolutions on the matter (Pakistan, 2006);

- 420 resulted in mild verbal expressions displaying discord in interaction, for example requesting a change in policy. The Russian authorities in response to the toxic spill from China called for sanction mechanisms. On November 13, a chemical plant explosion in China's northeast spewed toxins into the Songhua River - a tributary to the Amur River. As a consequence, the health of 650,000 inhabitants of the Russian city of Khabarovsk was endangered because its population relies on the Amur for water supply. President Vladimir Putin's envoy to the Far East, Kamil Iskhakov said: "To ward off the danger of repeated pollution of the river, we must get China to sign a final inter-state agreement with Russia and to ratify it, so sanctions could be applied for polluting the Amur" (Panic, 2005; International Water Events, 2011).

During the 60 years of water-related international relations analysed there was no case of a formal declaration of "water war" and 122 events were deemed to be neutral or non-significant acts for the inter-nation situation. Around 66 per cent of the total number of water-related international events of any intensity was weighted towards cooperation. Focusing only on relations connected with water quantity $59 \%$ cases over the period 1948-1999 proved to be cooperation events, while in the years 2000-2008 50\% (Edwards, Stefano, Silva, Wolf, 2010; International Water Events, 2011).

According to the study mentioned above, the Earth's waters have been rather a source of international cooperation than conflict because of a dominant riparian state, like Israel in the case of the Jordan River, usually is able to successfully reassure its perceived water rights, even if its actions limit the access of other states to precious resources. Constant competition over water between the Jordan River's basin between six countries has resulted both in conflict and cooperation between them, the majority being the latter. John K. Cooley, describing Israel relations with its Arab neighbours noticed: "[...] water is likely to cause wars, cement peace, and make and break empires and alliances in the region, as it has for thousands of years" (Cooley, 1984: 3). 


\section{RELATIONS BETWEEN RIPARIAN STATES OF THE JORDAN RIVER A CASE STUDY}

The Jordan basin covers about 18,500 square kilometers and is shared by the mutually antagonistic nations of Jordan (40 per cent of the basin territory), Israel (37 per cent), Syria ( 10 per cent), the West Bank ( 9 per cent) and Lebanon ( 4 per cent). The Jordan River is 250 kilometers long and originates from three rivers: the Dan, which begins in Israel, the Banias that begins in the Golan Heights and the Hasbani that begins in southern Lebanon. The three mentioned rivers merge and flow into Lake Tiberias, known as the Sea of Galilee (Irrigration, 2009: 82). The Lower Jordan River, beyond Lake Tiberias, receives water from its main tributary, the Yarmouk River that originates in Jordan. The Yarmouk River forms the border between Jordan and Syria and then between Jordan and Israel, and finally flows into the Lower Jordan River. The river forms the Israeli-Jordanian and West Bank-Jordanian borders and finally ends in the Dead Sea. Map 2 presents the flow of the Jordan River and its tributaries.

It can be said water is the most valuable resource in the Middle East and has become inseparably linked with national security. Renewable freshwater resources per capita are dramatically low in the case of Israelis who have at their disposal annually an average of 237 cubic meters and even less Jordanians - 143 cubic meters (Environmental Indicators, Inland Water Resources, 2011). The lack of freshwater is a development barrier in the areas of the Palestinian Authority and unequal water rights are one of the obstacles in Israeli-Palestinian relations.

Since the occupation of the West Bank, Israel has blocked Palestinians from physical access to the Jordan River. Water in springs and wells, available for Palestinians, comes from the Mountain Aquifer (composed of the Western, the Eastern and the North-Eastern sub aquifers, shared between Israel and the West Bank) and the Coastal Aquifer (shared between the Gaza Strip and Israel). Access to the former is strictly controlled by Israel. Water rights are mentioned in Article 40 of the Protocol Concerning Civil Affairs, which is Annex III to the 1995 Israeli-Palestinian Interim Agreement on the West Bank and the Gaza Strip. While estimating the "future needs" of the Palestinians in the West Bank at between 70 and 80 million cubic meters yearly, Israel recognised the "necessity to make available to the Palestinians during the interim period a total quantity of 28.6 million cubic meters (of fresh water for domestic use) per year" of which 5 million cubic meters is dedicated to Gaza from the Israeli water system (Israeli-Palestinian Interim Agreement, 1995). Further provisions on sharing water resources are supposed to be dealt during the "final status" Israel-Palestinian talks, which were never concluded.

Mekorot, Israel's main national water company, provides water in the West Bank. While Israeli settlers are getting subsidies for water, Palestinians are spending between 10 to 50 per cent of income to cover expenses connected with water use (Lipowska-Harmady, 2010). In the West Bank, the Israeli half of the million-settler population consumes approximately six times the amount of water used by the 2.6 million Palestinians (Koek, 2013: 16). Moreover, on the West Bank territory Palestinians applications to build new wells or deepen old ones are in the majority rejected by the Israeli-Palestinian Joint Water Committee, which approves the majority of Israeli 
Map 2. Jordan River flow

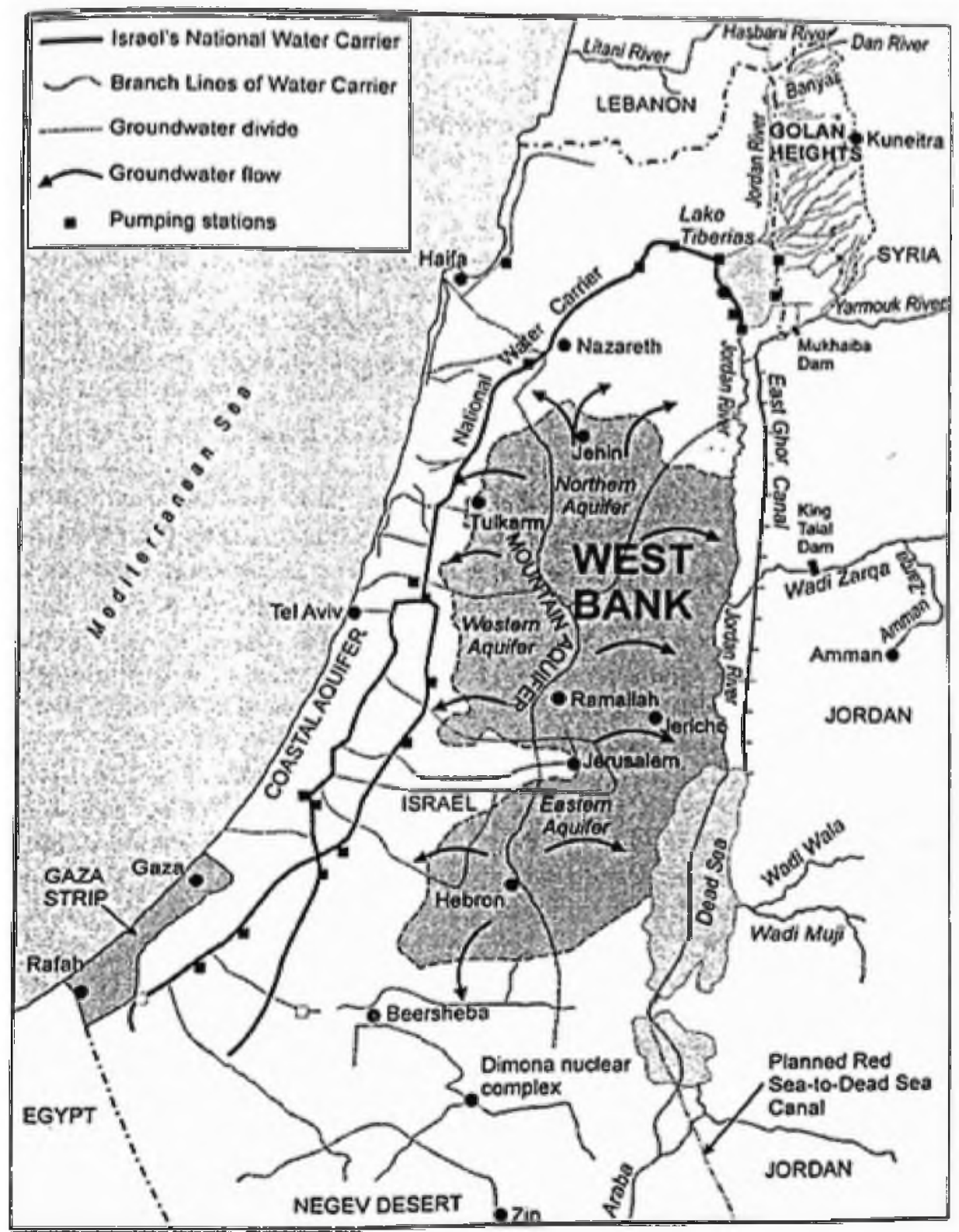

Source: B. Chellaney (2013), Water, Peace, and War Confronting the Global Water Crisis, Plymouth, p. 51.

applications. Many Palestinian villages, without any water supply, are forced to collect rainwater or to wait for costly delivery by truck (Ward, 2002: 189-190). The lack of a fair share of water resources therefore has deteriorated Israeli-Palestinian relations and is an obstacle to peace between antagonist nations. 
In 1919, the World Zionist Organization delegation at the Paris Peace Conference expressed the following standpoint: "The economic life of Palestine, like that of every other semi-arid country depends on the available water supply. It is, therefore, of vital importance not only to secure all the water resources already feeding the country, but also to be able to conserve and control them at their sources. Palestine must have [...] the control of its rivers and their headwaters" (Lowi, 1995: 40).

The events that led to Israel's 1967 war against Jordan, Syria and Egypt were connected with water rivalry between neighbouring countries. In 1953 Israel began preparing plans for the largest country water project known as the National Water Carrier. Construction began in 1956 and was finalized in 1964. The water artery is composed of aqueducts, pipelines, open channels, and pumping stations, made for transporting water 130 kilometers from Lake Tiberias through Israel up to the Negev desert (The National Water, 2014).

As the National Water Carrier diverts Jordan waters, during the Arab states summit in the beginning of 1964, Lebanon and Syria expressed their desire to finance a water-sharing project in the Upper Jordan River. What is more, all Arab countries decided to financially support building a dam on the Yarmouk River. In 1965 the next summit meeting took place and the Arab states announced a project named the Headwater Diversion Plan. The aim of the plan was to redirect flows from the Jordan's River headwaters to Syria and Jordan and prevent them from reaching Lake Tiberias.

The prepared plan of dividing waters in the upper part of the Jordan tributary meant decreasing by $35 \%$ the possibility of obtaining water by the National Water Carrier and assumed the diversion of waters from the River Hasban to the Litani River, as well as a similar operation from the Banias River to that of the Yarmouk, where it would be shared between Jordan and Syria with the aid of the Mukhaiba Dam (Kowalczak, 2007: 301-302).

In the period 1965-1966 the Israeli Air force conducted air raids on hydro-technical objects belonging to Syria, forcing it to suspend work on the construction of the dam on the River Yarmouk. In 1967 the Six-Day War broke out, resulting in Israel removing the hydrological infrastructure under construction of the Headwater Diversion Plan, as well as taking over the Golan Heights - an area supplying water to Jordan in the upper reaches of the river; except for the fragment of the Hasban River drainage, which made it impossible to decrease the course of the Jordan through Syria.

Moreover, Israel took control over the Western Bank of the Jordan and at the same time, secured for itself access to the river for most of its length, as well as the vast resources of subterranean water (the Mountain Aquifer). Israel in this context also destroyed the Mukhaiba dam on the Yarmouk River.

Ariel Sharon, who participated in the Six-Day War, stated: "People generally regarded June 5, 1967 as the day the Six-Day War began. That is the official date. In reality, however, it started two-and-a-half years earlier; on the day Israel decided to act against the diversion of the Jordan" (Chanoff, Sharon, 2001: 165). That strategy gave Israel the control of the main sub-regional groundwater resources and all of the Jordan River's headwaters, although Israel didn't manage to seize power over Lebanon's river Litani, which the Zionists included in their plan for securing future-state water supply. At present the West Bank's Mountain Aquifer and the Sea of Galilee give Israel about 
60 per cent of its fresh water and Israeli settlements, taking about 80 per cent of the Mountain Aquifer's flow (Asser, 2010).

Further relations between the Jordan River basin countries have created a record of water-related interactions. The 1994 Treaty of Peace between Israel and Jordan set the most comprehensive cooperation project in the region. That arrangement is the only peace pact that contains water-sharing provisions. According to Annex II titled Water-related Manners, Israel secured the right to pump 45 million cubic meters from the Yarmouk River per year, and in return it agreed to transfer to Jordan's King Abdullah Canal 20 million cubic meters from the Jordan River each summer. Jordan is entitled to store 20 million cubic meters of the Upper Jordan winter flow on the Israeli side (in Lake Tiberias) and get it back during the summer months. In addition, Jordan obtained access to an annual quantity of 10 million cubic meters of desalinated Israeli spring water. The Joint Water Committee, comprising three representatives from each country, was established to watch over implementation of Annex II (Treaty of Peace, 1994).

The management of water supply in the Jordan tributary is a complex issue on account of the decreasing availability of this 'blue gold' in the face of the growing human population, as well as the continuing Arab-Israeli conflict. The establishment of an International Commission for the Management of the River Jordan would give hope for a fair distribution of water supply for the Jordan. A treaty therefore between Israel and Jordan would be the first step towards establishing such an organisation and thus making possible to maintain the quality and quantity of water resources in respect to the River Jordan.

\section{BIBLIOGRAPHY}

Asser M. (2010), Obstacles to Arab-Israeli peace: Water, BBC News, http://www.bbc.com/news/ world-middle-east-11101797 (10.02.2016).

Atlas of Transboundary Aquffers. Global Maps, Regional Cooperation and Local Inventories (2009), UNESCO - International Hydrological Programme, Paris.

BAR Scale (2011), The Program in Water Conflict Management and Transformation, http://www.transboundarywaters.orst.edu/database/event_bar_scale.html (22.01.2016).

Blanchon D. (2013), Atlas mondial de l'eau, Paris.

Chalecky E. L. (2013), Environmental Security. A Guide to the Issues, Santa Barbara-Denver-Oxford.

Chellaney B. (2013), Water, Peace, and War Confronting the Global Water Crisis, Plymouth.

Chanoff D., Sharon A. (2001), Warrior: An Autobiography, New York.

Contribution of transboundary water to the total renewable water resources (2015), Map by Food and Agriculture Organization of the United Nations, http://www.fao.org/nr/water/aquastat/maps/ index.stm (8.01.2016).

Cooley J. K. (1984), The War over Water, "Foreign Policy", No. 54.

Crossette B. (1995), Severe Water Crisis Ahead for Poorest Nations in Next 2 Decades, "The New York Times", 10.08.1995.

Edwards P., Stefano L. De, Silva L. de, Wolf A. T. (2010), Tracking cooperation and conflict in international basins: historic and recent trends, "Water Policy", No. 12. 
Environmental Indicators, Inland Water Resources, United Nations Statistic Division, http://unstats.un.org/ unsd/environment/waterresources.htm (8.01.2016).

Facing the Challenges. Case Studies and Indicators (2015), UNESCO, Paris.

India protest over Pakistan dam (2006), BBC News, 8 March 2006, http://news.bbc.co.uk/2/hi/ south_asia/4787630.stm (21.01.2016).

International Water Events Database (2011), http://gis.nacse.org/tfdd/internationalEvents.php (18.01.2016).

Irrigation in the Middle East region in figures. FAO Water Report No. 34 (2009), (eds.) K. Frenken, Food and Agriculture Organization of the United Nations, Rome.

Israeli-Palestinian Interim Agreement on the West Bank and the Gaza Strip (1995), 26 September 1995, Washington, http://www.mfa.gov.il/MFA/ForeignPolicy/Peace/Guide/Pages/THE\%20ISRAELI-PALESTINIAN\%20INTERIM\%20AGREEMENT\%20-\%20Annex\%20III.aspx\#app-40 (8.02.2016).

Koek E. (2013), Water For One People Only. Discriminatory Access and 'Water-Apartheid' in the $O P T$, Al-Haq, Ramallah.

Kowalczak P. (2007), Konflikty o wodę, Przeźmierowo.

Kumar S. (2013), The Looming Threat of Water Scarcity, in: Vital Signs 2013. The Trends That Are Shaping Our Future, Vol. 20, The Worldwatch Institute.

Lowi M. R. (1995), Water and Power. The Politics of Scarce Resources in the Jordan River Basin, Cambridge.

Lipowska-Hamdy M. (2010), Niewidoczne oblicze konfliktu. Izraelsko-palestyńskie spory o wodę, http://www.woda.edu.pl/artykuly/niewidoczne_oblicze_konfliktu/ (9.02.2016).

MacQuarrie P., Wolf A. T. (2013), Understanding Water Security, in: Environmental Security, (eds.) R. Floyd, R. A. Matthew, Abington-New York.

Magsis B. O. (2015), International Water Law and the Quest for Common Security, Abington-New York.

Panic strikes as toxic slick reaches Russian city, (2005), "Gulf News", http:/gulfnews.com/news/europe/russia/panic-strikes-as-toxic-slick-reaches-russian-city-1.308959 (22.01.2016).

Pakistan rejects Indian protest on Bhasha dam (2006), DAWN, 9.03.2006, http://www.dawn.com/ news/182296/pakistan-rejects-indian-protest-on-bhasha-dam (21.01.2016).

Population Prospects: The 2015 Revision. Key Findings and Advanced Tables World (2015), United Nations Department of Economic and Social Affairs, New York.

Roller V. (2011), The Campaign Against UNPROFOR, http:/www.aimpress.ch/dyn/trae/archive/ data/199407/40702-001-trae-zag.htm (20.01.2016).

Sakson A. (2013), Utrata bezpieczeństwa żywnościowego jako źródlo wewnętrznych konfliktów zbrojnych w Darfurze, "Przegląd Strategiczny", No. 2.

Sosland J. K. (2007), Cooperating Rivals. The Riparian Politics of The Jordan River Basin, New York.

The Global Transboundary River Basins (2015), Transboundary Waters Assessment Programme, http://wap-rivers.org/\#global-basins (16.01.2016).

The National Water Carrier's Jubilee (2014), Israel National Water Company, http://www.mekorot.co.il/ Eng/newsite/Projects/NWC/Pages/NWCJubilee.aspx (12.02.2016).

The United Nations World Water Development Report 4: Managing Water under Uncertainty and Risk (2012), UNESCO, UN Water, World Water Assessment Programme, Vol. 1, Paris.

There are 276 transboundary river basins in the world (2014), United Nations Water. http://www.unwater.org/statistics/statistics-detail/en/c/211763/ (16.01.2016). 
Treaty of Peace between the State of Israel and the Hashemite Kingdom of Jordan, October 26, 1994. $\mathrm{http} / /$ www.mfa.gov.il/mfa/foreignpolicy/peace/guide/pages/israeljordan $\% 20$ peace $\% 20$ treaty.asx (16.02.2016).

Water Overview (2015), The World Bank, http:/www.worldbank.org/en/topic/water/overview (4.01.2016).

Water for Life Decade. Water Scarcity (2015), United Nations Department of Economic and Social Affairs, http://www.un.org/waterforlifedecade/scarcity.shtml (12.12.2015).

Water Mapping, measuring, and mitigating global water challenges (2015), World Resources Institute, http://www.wri.org/our-work/topics/water (12.12.2015).

Water Security and the Global Water Agenda (2013), United Nations University, Institute for Water. Environment and Health, Hamilton.

Water stress versus water scarcity (2014), United Nations Department of Economic and Social Affairs, http://www.un.org/waterforlifedecade/scarcity.shtml (12.12.2015).

Ward D. R. (2002), Water Wars. Drought, Flood, Folly, and the Politics of Thirst, New York.

World Development Indicators 2010 (2010), The World Bank, Washington.

Vela J. (2011), Kyrgyzstan and Tajikistan: Is Batken Province Central Asia's Next Flashpoint?, http://www.eurasianet.org/node/63640 (20.01.2016).

\begin{abstract}
The aim of the article is to explain the key definitions connected with water security and to analyse state relations in the context of water issues. In this context therefore water can be seen to be a precious resource because there it has no substitute. Thus the lack of water security is emerging as one of the major barriers for economic and social growth in developing countries and a source of domestic conflicts. On the other hand, water-related events might result in international cooperation, as Kofi Annan noticed during the celebration of World Water Day: "Fierce national competition over water resources has prompted fears that water issues contain the seeds of violent conflict. [...] If all world's peoples work together, a secure and sustainable water future can be ours". What is certain, in the near future any environmental security planning will have to take into consideration the prime issue of water security.
\end{abstract}

Key words: water security, water stress, water deficit, water conflict, natural resources, ecological security, environmental security

\title{
OGRANICZONY DOSTĘP DO WODY JAKO ZAGROŻENIE DLA BEZPIECZEŃSTWA PAŃSTWA
}

\section{STRESZCZENIE}

Woda jest tak cenna gdyż nie ma dla niej substytutu. Brak narodowego bezpieczeństwa ekologicznego w kontekście zasobów wody słodkiej staje się jedną z głównych przeszkód dla rozwoju ekonomiczno-społecznego państw oraz przyczyną wewnętrznych konfliktów. Należy jednak zauważyć, że kontakty państw na tle zagadnień związanych z wodą mogą prowadzić do międzynarodowej współpracy, na co wskazał w czasie obchodów Międzynarodowego Dnia Wody Kofi Annan, mówiąc: "Zaciekła państwowa rywalizacja o zasoby wody wzbudziła oba- 
wy, że problemy związane z wodą mogą byé zalążkiem brutalnego konfliktu. [...] Jeśli wszyscy ludzie na ziemi będą współpracować, czeka nas bezpieczna i stabilna przyszłość zasobów wodnych". Pewne jest, że w najbliższej przyszłości każde planowanie dotyczące bezpieczeństwa ekologicznego będzie obejmowało kwestie dotyczące wody. Artykuł powstał by wyjaśnić terminy związane $\mathrm{z}$ bezpieczeństwem ekologicznym w kontekście zasobów wody i dokonać oceny stosunków między państwami, odnoszących się to tego aspektu bezpieczeństwa.

Słowa kluczowe: bezpieczeństwo wodne, stres wodny, deficyt wody, konflikt o zasoby wody, zasoby naturalne, bezpieczeństwo ekologiczne 